\title{
Predicting Market Quality of Grapefruit after Hot-air Quarantine Treatment
}

\author{
Raymond G. McGuire and William F. Reeder \\ U.S. Department of Agriculture, Agricultural Research Service, Subtropical Horticulture Research \\ Station, 13601 Old Cutler Road, Miami, FL 33158 \\ Additional index words. Anastrepha suspensa, Citrus paradisi, decay, firmness, color \\ Abstract. Early, mid-, and late-season grapefruit (Citrus paradisi Macf.) were treated with hot air at 46, 48, and \\ $50 \mathrm{C}$ for 3, 5, or 7 hours to determine the effects of time and temperature on market quality. Early and late-season \\ fruit were more easily' damaged by the higher temperatures than midseason fruit. Increased times at the lower \\ temperatures had less of a deleterious effect on weight loss, loss of firmness and color, and susceptibility to scalding \\ injury and fungal decay than did shorter times at the higher temperatures. Nevertheless, regression equations pre- \\ dicted that 3 hours at $48 \mathrm{C}$ or 2 hours at $49 \mathrm{C}$ would not adversely affec: market quality of early and midseason fruit. \\ The suitability of these equations was verified through taste tests of Juice. It may not be possible, however, to raise \\ the treatment temperature for late-season fruit above $47.5 \mathrm{C}$ without damaging the quality of juice from these fruit.
}

Grapefruits have been an important export commodity from California, Texas, and Florida, yet the threat of fruit fly infestation is sufficient to restrict the movement of fruit unless it has first been treated to kill all life stages of these insects. The Caribbean fruit fly [Anastrepha suspensa (Loew)] is endemic in Florida and throughout the 1 Caribbean. This insect was controlled at one time by postharvest fumigation with ethylene dibromide (Grierson and Hayward, 1959), but use of this chemical has been discontinued. Currently, low-temperature storage, methyl bromide fumigation, and gamma irradiation are approved practices for fly eradication (U.S. Dept. of Agriculture, 1985). Although cold treatment; which requires 3 weeks and is usually performed aboard ship in transit, is satisfactory for export of fruit to Japan, shippers would prefer speedier and more economical treatment for fruit that is sent to the large California market. Fumigation with methyl bromide has been under review since the chemical was found to be carcinogenic in rats (Danse et al., 1984).

Heat treatment provides a quick alternative for insect disinfestation of various fruits and also offers some measure of disease control (Couey, 1989). However, to achieve the mandated probit 9 level of fly control of no more than three survivors per 100,000 treated insects, heat treatments often produce an unacceptably high level of injury in grapefruit (Miller et al., 1988; Sharp, 1985; Smoot and Melvin, 1965; Spalding and Reeder, 1985). At 43.3C, a probit 9 level of quarantine security is calculated to require $42.5 \mathrm{~min}$ to kill eggs of A. suspensa, the most resistant stage (Sharp and Chew, 1987). This temperature must be reached at the core of the fruit, yet when the center is $43.3 \mathrm{C}$, the outer tissue may have become several degrees warmer. When conventional hot-water immersion is the treatment method, scald is the usual result; this induces increased susceptibility to decay, primarily by species of Penicillium.

Treatment by forced hot air raises the temperature of fruit slowly, and the dewpoint temperature is maintained below the level at which condensation would form on the fruit (Sharp et al., 1991). With this treatment, scald can be avoided at moderately high temperatures (Sharp, 1989). A chamber tempera-

\footnotetext{
Received for publication 4 Sept. 1990. Accepted for publication 10 Sept. 1991 We appreciate the assistance provided by Jennifer Sharp and Victor Chew. Mention of a trade name does not constitute a recommendation by the U.S. Dept. of Agriculture. The cost of publishing this paper was defrayed in part by the payment of page charges. Under postal regulations, this paper therefore must be hereby marked advertisement solely to indicate this fact.
}

ture of $46 \mathrm{C}$ produces a calculated probit 9 level of kill in 2.95 $\mathrm{h}$ when the initial fruit temperature is $24 \mathrm{C}$.

The response of grapefruit to hot-air treatment above $46 \mathrm{C}$ has not been tested. Such higher temperatures may become necessary for eradication when insects are especially resistant to heat or when shorter treatment times are preferable. In this report, several combinations of temperatures and times of treatment are used as bases for predicting the market quality of grapefruit following hot-air quarantine procedures.

\section{Materials and Methods}

Early, middle, and late-season 'Marsh' white grapefruit were obtained from Oct. 1989 through Apr. 1990, graded and degreened if necessary but otherwise unprocessed, from a packing house in central Florida. The three harvests, representing random lots of fruit, were considered to be experimental replications. Fruit were initially washed then separated into nine treatments that included combinations of temperature at 46,48 , or $50 \mathrm{C}$ and times at 3,5 , or $7 \mathrm{~h}$, and control fruit that were not heated. Each of three subsamples of a treatment, determined by position in the hot-air chamber relative to the source of heat, contained 36 fruit with an average weight of $\approx 450 \mathrm{~g} /$ fruit. All treatments were completed within 3 days, during which the fruit were stored at 13C [95\% relative humidity (RH)] until their removal to $22 \mathrm{C} 24 \mathrm{~h}$ before treatment. The fruit were weighed immediately before treatment.

For treatment with forced hot air, 36 fruit were placed into each of three $60 \times 40 \times 31-\mathrm{cm}$ plastic bins with bottoms of steel grating. The bins were stacked within the hot-air chamber, and air at 46,48 , or $50 \mathrm{C}$ (from $58 \%$ to $90 \% \mathrm{RH}$ ) was forced through the sealed chamber at an average $0.4 \mathrm{~m}^{3} \cdot \mathrm{s}^{-1}$ for the designated period. The heating of the chamber was controlled by a computer program using the temperatures in the outer 1 $\mathrm{mm}$ of three fruit at the base of the column as input; these temperatures were monitored every $60 \mathrm{sec}$ using Type T copper constantan thermocouples (Sharp et al., 1991). Temperatures in the cores of 10 fruit/treatment were monitored similarly. When treatments were complete, fruit were waxed using Fresh Wax 3202 (Fresh Mark Corp., Ocoee, Fla.), a standard commercial practice, in a packing-line facility. Treated fruit were stored at 13C.

After 28 days of cold storage, fruit were evaluated for weight

Abbreviation: TSS, total soluble solids. 
loss and visually rated for the incidence of decay and the severity of injury as described by Spalding and Reeder (1985). Firmness of each fruit was measured at two equatorial sites using an Instron model 1011 (Instron, Instron Corp., Canton, Mass.) fitted with a 5.75-cm-diameter compression anvil; resistance to pressure was recorded after a compression of $5 \mathrm{~mm}$ and averaged per fruit. Color evaluations were made at four sites about the equator of each fruit using a Minolta CR-200 chroma meter (Minolta Corp., Ramsey, N. J.) recording in the Hunter L, a, b system (Francis, 1980). As recommended by Little (1975), hue angle (arctangent b/a) and saturation index $\left[\left(a^{2}+b^{2}\right)^{1 / 2}\right]$ were calculated, then average values were determined for individual fruit for subsequent statistical analyses. Ten fruit from each subsample of each treatment and the control were also individually juiced; $\mathrm{pH}$, titratable acidity, expressed as anhydrous citric acid, and total soluble solids concentrations (TSS) were measured as described by Hatton and Reeder (1968). In four informal sensory tests, 10 to 12 people compared three samples of juice from selected treatments and rated them from most to least preferred. Each taste test was replicated once using juice from another composite of four different fruit.

The data were tested with an analysis of variance and means separation (Ryan-Einot-Gabriel-Welsch multiple F test) in SAS (1985). Response data were analyzed directly, except for decay incidence, which was transformed into the arcsin of the square root of the proportion, and hue angle, which was converted from a scale of $-90^{\circ}$ to $90^{\circ}$ into one of $0^{\circ}$ to $180^{\circ}$, a range more appropriate for grapefruit. Subsequently, equations were generated that related $\log _{10}$ response to temperature and $\log _{10}$ time (Couey, 1989) using a 'C' value (minimum effective temperature) calculated by nonlinear regression in SAS. By substituting into these equations acceptable values for the response variables obtained from control fruit or published standards, maximum treatment times at specific temperatures were calculated. Sensory tests were statistically evaluated according to Fisher and Yates (1949) using scores for ranked data.

\section{Results}

The quality of fruit treated with heat for several hours would be expected to change, but in these trials differences were also superimposed upon changes resulting from 4 weeks in cold storage. Throughout these trials, the incidence of decay and the severity of injury in control fruit after storage averaged between 0 and $1 \%$ (Table 1). Control fruit from the early part of the season lost an average of $2.56 \%$ of their weight during storage. This weight loss increased for fruit picked as the season advanced-to $2.83 \%$ at midseason and to $3.23 \%$ for late-season fruit that were initially least firm. Although differences in peel color and juice $\mathrm{pH}$ after storage were not apparent among dates of harvest, fruit picked late in the season also had a lower percentage of titratable acidity, a higher percentage of TSS, and a correspondingly higher ratio of TSS to acid.

The temperature of hot-air treatment and the duration of treatment were statistically significant factors influencing the subsequent incidence of grapefruit decay in cold storage (Table 2). Higher temperatures or longer treatment times increased decay over the storage peroid. An interaction between time and temperature was not evident. The date of harvest did not statistically influence the susceptibility of the fruit to decay, nor were there significant interactions between that date and the treatment variables. One equation, therefore, with $42 \mathrm{C}$ being the minimum effective temperature, was sufficient to describe the percentage
Table 1. Quality of untreated, waxed grapefruit stored 4 weeks at $13 \mathrm{C}$ and $95 \% \mathrm{RH}$.

\begin{tabular}{lrrr}
\hline \hline & \multicolumn{3}{c}{ Season } \\
\cline { 2 - 4 } Criterion & \multicolumn{1}{c}{ Early $^{z}$} & \multicolumn{1}{c}{ Middle $^{z}$} & \multicolumn{1}{c}{ Late $^{z}$} \\
\hline Decay (\%) & $0.93 \pm 0.19$ & $0.93 \pm 0.19$ & \multicolumn{1}{l}{0} \\
Injury (\%) & $1.16 \pm 4.15$ & $0.14 \pm 1.62$ & $0.75 \pm 5.40$ \\
Weight loss (\%) & $2.56 \pm 0.64$ & $2.83 \pm 1.19$ & $3.23 \pm 0.82$ \\
Firmness (N) & $30.60 \pm 6.55$ & $32.50 \pm 6.57$ & $24.50 \pm 5.97$ \\
Color & & & \\
$\quad$ L & $77.09 \pm 3.04$ & $76.96 \pm 2.93$ & $77.31 \pm 3.63$ \\
$\theta$ & $91.75 \pm 2.56$ & $92.29 \pm 3.13$ & $91.61 \pm 2.70$ \\
s & $55.70 \pm 3.76$ & $56.69 \pm 4.01$ & $54.45 \pm 5.20$ \\
Juice & & & \\
$\quad$ pH & $3.39 \pm 0.10$ & $3.50 \pm 0.20$ & $3.44 \pm 0.18$ \\
Acid (\%) & $1.30 \pm 0.39$ & $1.27 \pm 0.26$ & $0.96 \pm 0.26$ \\
TSS (\%) & $9.23 \pm 1.10$ & $10.64 \pm 1.00$ & $12.33 \pm 1.10$ \\
TSS : acid & $7.29 \pm 2.19$ & $8.49 \pm 1.88$ & $13.06 \pm 4.01$ \\
\hline \hline
\end{tabular}

${ }^{\mathrm{z}}$ Mean of 108 fruit (decay incidence, injury severity, weight loss, color), 90 fruit (firmness), or 30 fruit (juice), and $95 \%$ confidence intervals. 'Color: $\mathrm{L}=$ darkness, $\theta=$ hue angle, $\mathrm{s}=$ saturation index.

of decay throughout these trials: $\log _{10}$ Decay $(\%)=-4.656+$ $2.548 \times \log _{10}$ time $+0.602 \times($ temp -42$),\left(r^{2}=0.8156\right)$.

The severity of injury that resulted from treatment of grapefruit with hot air also depended on the temperature and duration of application (Table 2). Surface injury, primarily pitting and scald, averaged $<2 \%$ in each trial when fruit were exposed to $46 \mathrm{C}$ for as long as $7 \mathrm{~h}$. At 50C, however, this injury varied from $30 \%$ at midseason to $70 \%$ at early and late season (detailed data not shown). Overall, midseason fruit were least susceptible to injury (Table 1) and most resistant to heat damage. An interaction between season and treatment temperature required three equations to describe the expected injury to grapefruit from hot-air treatment at early, mid-, and late season, respectively: $\log _{10}$ Injury $(\%)=-1.381+1.815 \times \log _{10}$ time $+0.397 \times$ (temp - 45), $\left(\mathrm{r}^{2}=0.8728\right) . \log _{10}$ Injury $(\%)=-0.450+$ $1.019 \times \log _{10}$ time $+0.425 \times($ temp -47$),\left(r^{2}=0.9338\right)$. $\log _{10}$ Injury $(\%)=-0.893+1.455 \times \log _{10}$ time $+0.398 \times$ (temp - 46), $\left(r^{2}=0.8875\right)$.

Weight loss was significantly affected by both time and temperature of hot-air treatment but not by an interaction of the two (Table 2). Even the least severe treatment, 3 hat $46 \mathrm{C}$, produced a significant $(P=0.001)$ increase in weight loss over control fruit and averaged $3.48 \%, 3.46 \%$, and $4.64 \%$ at the successive harvests. Date of harvest was an important factor, with lateseason fruit most susceptible to weight loss. The interaction between season and treatment temperature required two equations to describe this variable; for early and midseason: $\log _{10}$ Weight loss $(\%)=0.500+0.087 \times \log _{10}$ time +0.009 $\times($ temp -47$),\left(r^{2}=0.5342\right)$. For late season: $\log _{10}$ Weight loss $(\%)=0.486+0.153 \times \log _{10}$ time $+0.028 \times($ temp $43),\left(r^{2}=0.5642\right)$,

The temperature and time of hot-air treatment, and their interaction, significantly affected the resulting firmness of grapefruit (Table 2). Firmness of the fruit was reduced with higher treatment temperatures and over longer periods of treatment. The position of the fruit within the hot-air chamber significantly affected firmness; fruit that had been closer to the heat source became less firm during storage, and this effect was compounded by the time and temperature of treatment. Late-season fruit were initially less firm, but their response to heat was similar to that of midseason fruit. Early season fruit, however, responded differently to heat. Thus, interactions between date 
Table 2. Analysis of grapefruit quality following hot-air treatment at 46,48 , or $50 \mathrm{C}$ for 3 , 5 , or $7 \mathrm{~h}$.

\begin{tabular}{|c|c|c|c|c|c|c|c|c|c|}
\hline \multirow[b]{2}{*}{ Variable } & \multirow[b]{2}{*}{$\mathrm{df}^{z, y}$} & \multicolumn{2}{|c|}{ Decay incidence (\%) } & \multicolumn{2}{|c|}{ Injury severity (\%) } & \multicolumn{2}{|c|}{ Wt loss $(\%)$} & \multicolumn{2}{|c|}{ Firmness (N) } \\
\hline & & MS & F value & MS & F value & MS & F value & MS & F value \\
\hline$\overline{\text { Season }(\mathrm{Se})}$ & 2 & 0.1754 & NS & 17.60 & $11.70^{* *}$ & 17.166 & $79.58^{* * *}$ & 278.62 & $232.50^{* * *}$ \\
\hline Temp (Te) & 2 & 9.3752 & $69.50 * * *$ & 183.38 & $121.89^{* * *}$ & 3.357 & $15.57^{* * *}$ & 1455.54 & $1214.56^{* * *}$ \\
\hline Time (Ti) & 2 & 0.6927 & $5.14^{*}$ & 10.59 & $7.04^{* *}$ & 1.547 & $7.17^{* *}$ & 264.00 & $220.29 * * *$ \\
\hline $\mathrm{Te} \times \mathrm{Ti}^{\prime}$ & 4 & 0.1672 & NS & 2.95 & NS & 0.351 & NS & 143.24 & $119.52^{* * *}$ \\
\hline $\mathrm{Se} \times \mathrm{Te}$ & 4 & 0.0418 & NS & 6.05 & $4.02^{*}$ & 1.167 & $5.41^{*}$ & 19.06 & $15.91 * * *$ \\
\hline $\mathrm{Se} \times \mathrm{Ti}$ & 4 & 0.0988 & NS & 1.86 & NS & 0.390 & NS & 4.11 & $3.43^{*}$ \\
\hline Error a & 8 & 0.1349 & & 1.50 & & 0.216 & & 1.20 & \\
\hline Height (Ht). & 2 & 0.0018 & NS & 0.45 & NS & 0.023 & NS & 3.84 & $3.55^{*}$ \\
\hline $\mathrm{Ht} \times \mathrm{Se}$ & 4 & 0.0086 & NS & 0.11 & NS & 0.077 & $3.17^{*}$ & 1.14 & NS \\
\hline $\mathrm{Ht} \times \mathrm{Te} \times \mathrm{Ti}$ & 16 & 0.0065 & NS & 0.33 & NS & 0.023 & NS & 2.24 & $2.07^{*}$ \\
\hline \multirow[t]{2}{*}{ Error b } & 32 & 0.0065 & & 0.17 & & 0.025 & & 1.08 & \\
\hline & \multicolumn{9}{|c|}{ Means of variables } \\
\hline \multicolumn{10}{|l|}{ Season } \\
\hline Early & r & $31.38 \mathrm{a}$ & & $29.68 \mathrm{a}$ & & $3.75 \mathrm{a}$ & & $24.5 z \mathrm{a}$ & \\
\hline Mid & & $28.40 \mathrm{a}$ & & $13.54 \mathrm{~b}$ & & $3.69 \mathrm{a}$ & & $25.64 \mathrm{a}$ & \\
\hline Late & & $37.96 \mathrm{a}$ & & $22.19 \mathrm{a}$ & & $5.09 \mathrm{~b}$ & $v$ & $19.60 \mathrm{~b}$ & \\
\hline \multicolumn{10}{|l|}{ Temp } \\
\hline 46 & & 1.24 & & 1.57 & & 3.90 & & 28.36 & \\
\hline 48 & & 15.64 & & 12.62 & & 4.04 & & 26.56 & \\
\hline 50 & & 80.86 & & 51.21 & & 4.57 & & 14.84 & \\
\hline \multicolumn{10}{|l|}{ Time } \\
\hline 3 & & 20.27 & & 15.64 & & 3.90 & & 26.80 & \\
\hline 5 & & 37.14 & & 21.61 & & 4.35 & & 22.09 & \\
\hline 7 & & 40.33 & & 28.16 & & 4.27 & & 20.87 & \\
\hline
\end{tabular}

${ }^{2} \mathrm{df}=$ degrees of freedom; MS = mean square.

${ }^{y}$ The term $\mathrm{Ht} \times \mathrm{Te} \times \mathrm{Ti}$ is a combination of $\mathrm{Ht} \times \mathrm{Te}, \mathrm{Ht} \times \mathrm{Ti}$, and $\mathrm{Ht} \times \mathrm{Te} \times \mathrm{Ti}$.

'Within columm of the variable Season, numbers followed by the same letter are not significantly different at $P=0.05$ according to the RyanEinot-Gabriel-Welsh multiple F test. Means for decay, injury, and weight loss of 972 fruit and for firmness of 810 fruit.

$\mathrm{NS}, *, * *, * * *$ Nonsignificant or $\mathrm{F}$ value significant at $P=0.05,0.01$, or 0.001 , respectively.

of harvest and temperature, or differences in the initial quality of the fruit, required three equations to describe the effects on firmness. For early, mid-, and late-season, respectively: $\log _{10}$ Firmness $(\mathrm{N})=1.911-0.386 \times \log _{10}$ time $-0.056 \times$ (temp - 43), $\left(r^{2}=0.6039\right)$. $\operatorname{Iog}_{10}$ Firmness $(\mathrm{N})=1.898$ $0.399 \times \log _{10}$ time $-0.084 \times($ temp -45$),\left(r^{2}=0.6309\right)$. $\log _{10}$ Firmness $(\mathrm{N})=1.889-0.480 \times \log _{10}$ time $-0.107 \times$ (temp - 45), $\left(r^{2}=0.6539\right)$.

The color indices darkness, hue angle, and saturation were used to determine the effects of time and temperature of hot-air treatment on the external color of the grapefruit. The effect of harvest date was significant (Table 3); early and late-season fruit were most susceptible to scald, measured as a decrease in hue angle below $85^{\circ}$ and visible as a reddening of the fruit. Fruit darkness and color saturation were similarly affected by the season of harvest. Time, temperature, and an interaction between the two significantly affected peel color. Darkness, hue angle, and color intensity were all reduced by elevated temperatures and times of treatment. Interactions between temperature, time, and height, although $0.05<P<0.10$, suggested a positional effect within the hot-air chamber; as the treatments became more extreme, fruit nearer the heat source were more affected. Significant interactions between season of harvest and treatment temperature required two equations to describe the treatment effects. Hue angle was chosen as representative of the color indices; for early and late seasons: $\log _{10}$ Hue angle $=$ $2.029-0.092 \times \log _{10}$ time $-0.019 \times($ temp -46$),\left(r^{2}=\right.$ $0.7351)$. For midseason: $\log _{10}$ Hue angle $=1.967-0.012 \mathrm{x}$ $\log _{10}$ time $-0.004 \times($ temp -47$),\left(r^{2}=0.9789\right)$.

Temperature of hot-air treatment, but not length of treatment, was significant in its effect on TSS and titratable acidity in grapefruit juice (Table 4). With higher temperatures, the percentage of TSS increased, and the percentage of anhydrous citric acid was reduced. An interaction between temperature and time significantly affected the percentage of TSS. The TSS : acid ratio, more susceptible than either variable alone to both time and temperature of treatment, surpassed acceptable limits in some cases. As the season progressed and juice became significantly less acidic and more sweet (Table 1), the effects of hotair treatment on the TSS : acid ratio became more pronounced. The minimum effective temperature declined from $48 \mathrm{C}$ early in the season to $46 \mathrm{C}$ toward the end. No significant interaction was apparent between season and time or temperature of treatment; however, significant seasonal effects required individual equations to describe treatment effects. For the early season, $\log _{10}$ TSS : Acid $=0.906+0.005 \times \log _{10}$ time $+0.021 \times$ (temp - 48), $(\mathrm{P}=0.3216)$. For midseason: $\log _{10} \mathrm{TSS}$ : Acid $=0.938+0.122 \times \log _{10}$ time $+0.023 \times($ temp -47$),\left(r^{2}=\right.$ $0.6557)$. For late season: $\log _{10}$ TSS : Acid $=1.044+0.221 \times$ $\log _{10}$ time $+0.019 \times($ temp -46$),\left(r^{2}=0.7375\right)$.

In informal taste tests of juice from grapefruit harvested in early and midseason (tests 1-3), no difference in flavor could be found between control fruit and those treated at $46 \mathrm{C}$ for $5 \mathrm{~h}$ or at $48 \mathrm{C}$ for $3 \mathrm{~h}$ (Table 5). However, juice from fruit treated at $48 \mathrm{C}$ for $7 \mathrm{~h}$ in test 3 was significantly less palatable than that of control fruit or fruit treated at $48 \mathrm{C}$ for $3 \mathrm{~h}$. In contrast, juice of late-season grapefruit (test 4 ) treated at $46 \mathrm{C}$ for $5 \mathrm{~h}$ or at $48 \mathrm{C}$ for $3 \mathrm{~h}$ was considered significantly inferior to that from nontreated fruit.

By selecting specific values to replace the variables decay, 
Table 3. Analysis of peel color following hot-air treatment of grapefruit at 46,48 , or $50 \mathrm{C}$ for 3,5 , or $7 \mathrm{~h}$.

\begin{tabular}{|c|c|c|c|c|c|c|c|}
\hline \multirow[b]{3}{*}{ Variable } & \multirow[b]{3}{*}{$d f^{z, y}$} & \multicolumn{6}{|c|}{ Color index } \\
\hline & & \multicolumn{2}{|c|}{ Darkness } & \multicolumn{2}{|c|}{ Hue angle } & \multicolumn{2}{|c|}{ Saturation } \\
\hline & & MS & $\mathrm{F}$ value & MS & $F$ value & MS & F value \\
\hline Season (Se) & 2 & 163.96 & $30.85^{* * * *}$ & 217.17 & $14.26^{* * *}$ & 839.73 & $251.05^{* * * *}$ \\
\hline Temp (Te) & 2 & 1373.19 & $258.36^{* * * *}$ & 865.86 & $56.85^{* * * *}$ & 4314.50 & $1289.91^{* * * *}$ \\
\hline Time (Ti) & 2 & 111.28 & $20.94 * * * *$ & 132.89 & $8.72 * * *$ & 111.51 & $33.34 * * * *$ \\
\hline $\mathrm{Te} \times \mathrm{Ti}$ & 4 & 38.58 & $7.26^{* * *}$ & 62.56 & $4.11^{* *}$ & 44.53 & $13.31^{* * * *}$ \\
\hline $\mathrm{Se} \times \mathrm{Te}$ & 4 & 117.11 & $22.03^{* * * *}$ & 118.53 & $7.78^{* * *}$ & 464.39 & $138.84^{* * * *}$ \\
\hline $\mathrm{Se} \times \mathrm{Ti}$ & 4 & 10.32 & NS & 21.24 & NS & 7.35 & NS \\
\hline Error a & 8 & 5.32 & & 15.23 & & 3.34 & \\
\hline Height $(\mathrm{Ht})$ & 2 & 0.35 & NS & 0.11 & NS & 0.30 & NS \\
\hline $\mathrm{Ht} \times \mathrm{Se}$ & 4 & 0.32 & NS & 0.11 & NS & 0.79 & NS \\
\hline $\mathrm{Ht} \times \mathrm{Te} \times \mathrm{Ti}$ & 16 & 0.47 & $1.71^{*}$ & 0.64 & $1.78^{*}$ & 0.55 & NS \\
\hline \multirow[t]{2}{*}{ Error b } & 32 & 0.27 & & 0.36 & & 0.56 & \\
\hline & & \multirow{2}{*}{\multicolumn{6}{|c|}{ Means of variables }} \\
\hline \multicolumn{3}{|l|}{ Season } & & & & & \\
\hline Early & & $70.05 \mathrm{a}$ & & $85.13 \mathrm{a}$ & & $45.87 \mathrm{a}$ & \\
\hline Mid & & $74.23 \mathrm{~b}$ & & $90.22 \mathrm{~b}$ & & $54.98 \mathrm{~b}$ & \\
\hline Late & & $69.84 \mathrm{a}$ & & $85.51 \mathrm{a}$ & & $44.84 \mathrm{a}$ & \\
\hline \multicolumn{8}{|l|}{ Temp } \\
\hline 46 & & 76.49 & & 91.16 & & 56.50 & \\
\hline 48 & & 74.44 & & 89.20 & & 55.21 & \\
\hline 50 & & 63.24 & & 80.52 & & 33.99 & \\
\hline \multicolumn{8}{|l|}{ Time } \\
\hline 3 & & 73.64 & & 89.34 & & 50.82 & \\
\hline 5 & & 70.83 & & 86.58 & & 47.99 & \\
\hline 7 & & 69.70 & & 84.95 & & 46.88 & \\
\hline
\end{tabular}

${ }^{y}$ The term $\mathrm{Ht} \times \mathrm{Te} \times \mathrm{Ti}$ is a combination of $\mathrm{Ht} \times \mathrm{Te}, \mathrm{Ht} \times \mathrm{Te} \times \mathrm{Ti}$.

${ }^{x}$ Within columns of the variable Season, numbers followed by the same letter are not significantly different at $\mathrm{P}=0.05$ according to the Ryan-Einot-Gabriel-Welsh multiple $\mathrm{F}$ test. Means of 972

NS $, * * *, * * *, * * * *$ Nonsignificant or F value significant at $P=0.10,0.05,0.01$, or 0.001 , Respectively.

firmness, etc., in the above equations, a range of hot-air treatments was defined that likely will minimize injurious effects yet provide acceptable insect control. For these equations, maximum decay was set at $1.5 \%$ and surface injury at $4 \%$. Weight loss and firmness (for early or mid- and late-season fruit, respectively) were set at $3.7 \%$ and $27.5 \mathrm{~N}$ and at $5 \%$ and $22 \mathrm{~N}$. The color index of hue angle was set at $\geq 88.0^{\circ}$. For juice prepared at all three harvests, the minimum amount of anhydrous citric acid was set at $0.75 \%$, and the TSS : acid ratio was maximized at 13.89:1.

Within these constraints for market quality, presumptive limits for hot-air treatment of grape fruit were created (Fig. 1A-F). At $48 \mathrm{C}$, treatment times up to $3 \mathrm{~h}$ did not appear to adversely affect the quality of early and midseason fruit. Seven hours was tolerated at $46 \mathrm{C}$ where loss of firmness was the most limiting factor for hot-air treatment. Above 48C, increased susceptibility to decay and injury became the greater consideration; nevertheless, these fruit would appear to tolerate $2 \mathrm{~h}$ at $49 \mathrm{C}$ and perhaps $1 \mathrm{~h}$ at 50C. For fruit treated late in the season, an acidity below allowable limits and a correspondingly high TSS : acid ratio could limit the use of hot air to temperatures below 47.5C.

\section{Discussion}

Although this research dealt with heat treatments for eradication of Anastrepha suspensa from grapefruit in Florida, it is applicable wherever the crop is grown and hot air maybe used for insect or disease control. Within the United States, grapefruit grown in Texas and southwestern states may become infested with A. ludens (Loew), while that in Hawaii may harbor Dacus dorsalis Hendel, D. cucurbitae (Coquillet), and Ceratitis capitata (Wiedemann) (Harris, 1989). Japan, a major importer of American grapefruit, quarantines fruit that may transport species of the genera Anastrepha, Ceratitis, and Dacus (Koyama, 1989). California, as another example, also excludes grapefruit that may carry species of fruit fly (Harris, 1989). Both locations offer immense markets to citrus growers.

Grapefruit bound by ship for Japan maybe successfully treated to kill Anastrepha fruit flies by subjecting the fruit to $1.6 \mathrm{C}$ for 14 days (U.S. Dept. of Agriculture, 1985). To reduce chilling injury, fruit must be conditioned at $16 \mathrm{C}$ for an additional 7 days before the cold treatment (Hatton and Cubbedge, 1982). Within the continental United States, however, the time required for cold treatment may be disadvantageous; trucks can move the produce across the country in $72 \mathrm{~h}$, and the extra storage time can be costly. Radiation and chemical treatments to kill flies are rapid, but they appear to be unattractive to many consumers.

Treatment with hot air to eliminate insect infestations in fruit can be accomplished without contaminating the environment or alarming consumers. At 46C, use of the hot-air chamber can avoid the scalding injury that may occur when grapefruit are submerged in hot water (Sharp, 1989). However, treatment at this temperature may be too lengthy for packinghouse operations handling 200 to $500 \mathrm{t}$ of fruit daily (Sharp, 1989).

From this research, equations were generated to predict market quality of grapefruit treated with hot air at $46 \mathrm{C}$ and above. In most cases, setting the limit for an injurious effect had to be 

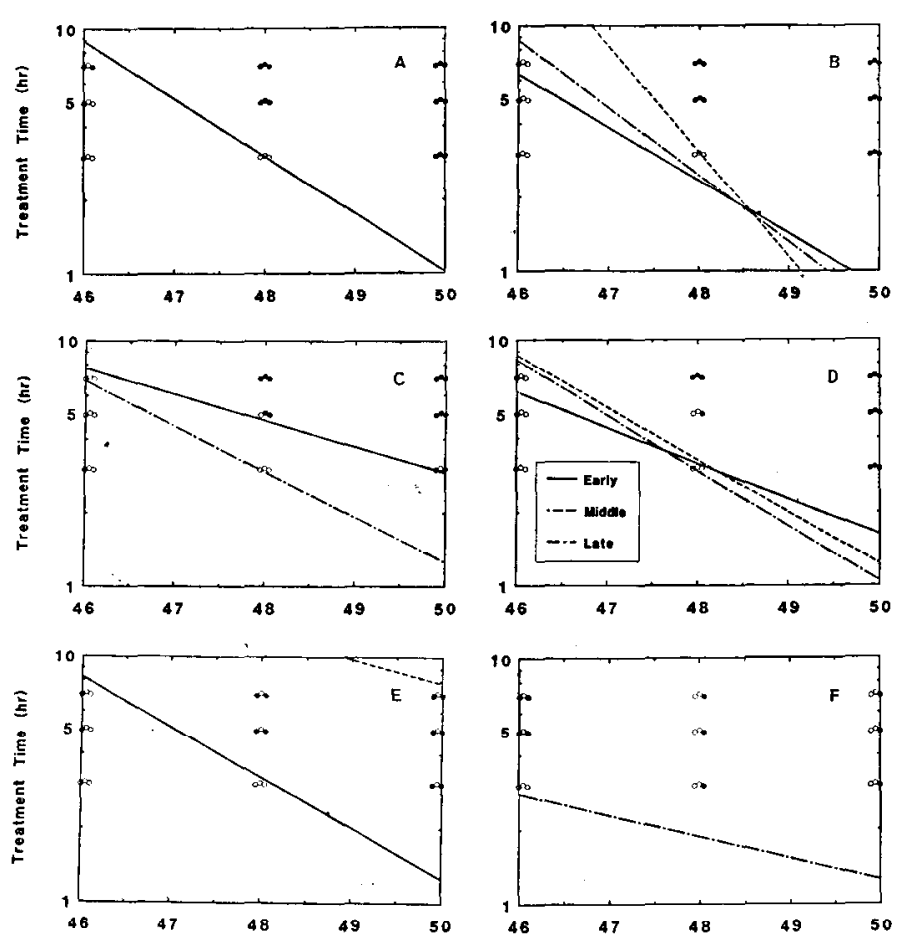

Fig. 1. Plots of limits set on market quality predicted from equations of multiple regression and defined from hot-air treatments of grapefruit at 46,48 , or $50 \mathrm{C}$ for 3,5 , or $7 \mathrm{~h}$. Initial fruit temperature was $22 \mathrm{C}$; mean fruit weight was $450 \mathrm{~g}$. (O) Acceptable quality, (O) unacceptable. (A) Decay: for all seasons $\leq 1.5 \%$. Plots for all seasons are colinear. (B) Injury: for all seasons $\leq 4.0 \%$. (C) Weight loss: early and midseason $\leq 3.7 \%$; late season $\leq 5 \%$. Plots for early and midseason are colinear. (D) Firmness: early and midseason fruit $\geq 27.5 \mathrm{~N}$; late-season fruit $\geq 22.0 \mathrm{~N}$. (E) Color hue angle: for all seasons $\geq 88.0^{\circ}$. Plots for early and late season are colinear. (F) Ratio of percent TSS to percent acid in juice: for all seasons $\leq 13.89$. Plots for early and midseason lie above $10 \mathrm{~h}$.

grapefruit is above $43.3 \mathrm{C}$ is the most critical for disinfestation (Sharp and Chew, 1987). The acceptability of quarantine treatments can be predicted by adding the heating time and the killing time; the sum of these times should not exceed the limits set here. A treatment under $3 \mathrm{~h}$ at $48 \mathrm{C}$, for example, should not be injurious to early and midseason fruit. This treatment time could be reduced by raising the initial temperature of the fruit, thus reducing the heating time required. However, unless significant changes in juice quality are acceptable, treatments below $47.5 \mathrm{C}$ maybe the only choices available for late-season fruit.

\section{Literature Cited}

Benschoter, C.A. 1979. Seasonal variation in tolerance of Florida 'Marsh' grapefruit to a combination of methyl bromide fumigation and cold storage. Proc. Fla. State Hort. Soc. 92:166-167.
Carter, R.D. 1983. Florida grapefruit juice from concentrate: Reconstitution, packaging, and distribution. Technical Manual, Florida Dept. of Citrus, Lakeland.

Couey, H.M. 1989. Heat treatment for control of postharvest diseases and insect pests of fruits. HortScience 24:198-200.

Danse, L. H. J. C., F.L. van Velson, and C.A. van der Heuden. 1984. Methylbromide: Carcinogenic effects in the rat forestomach. Toxicol. Appl. Pharmacol. 72262-271.

Fisher, R.A. and F. Yates. 1949. Statistical tables for biological, agricultural and medical research. 3rd ed. Oliver and Boyd, London.

Francis, F.J. 1980. Color quality evaluation of horticultural crops. HortScience 15:58-59.

Grierson, W. and F.W. Hayward. 1959. Fumigation of Florida citrus fruit with ethylene dibromide. Proc. Amer. Soc. Hort. Sci. 73:267277.

Harding, P.L. and D.F. Fisher. 1945. Seasonal changes in Florida grapefruit. U.S. Dept. Agr. Tech. Bul. 886.

Harris, E.J. 1989. Pest status: Hawaiian islands and North America, p. 73-80. In: A.S. Robinson and G. Hooper (eds.). Fruit flies: Their biology, natural enemies, and control. vol. 3A. World crop pests. Elsevier Science Publishers B.V. Amsterdam, The Netherlands.

Hatton, T.T. and R.H. Cubbedge. 1982. Conditioning Florida grapefruit to reduce chilling injury during low-temperature storage. J. Amer. Soc. Hort. Sci. 107:57-60.

Hatton, T.T. and W.F. Reeder. 1968. Quality of Persian limes after different packinghouse treatments and storage in various controlled atmospheres. Proc. Amer. Soc. Hort. Sci. 11:23-32.

Koyama, J. 1989. Pest status: South-east Asia and Japan, p. 63-66. In: A.S. Robinson and G. Hooper (eds.). Fruit flies: Their biology, natural enemies, and control. vol. 3A. World crop pests. Elsevier Science Publishers B.V. Amsterdam, The Netherlands.

Little, A.C. 1975. Off on a tangent. J. Food Sci. 40:410-411.

Miller, W. R., R.E. McDonald, T.T. Hatton, and M. Ismail 1988. Phytotoxicity to grapefruit exposed to hot water immersion treatment. Proc. Fla. State Hort. Soc. 101:192-195.

SAS Institute. 1985. SAS user's guide: Statistics. SAS Institute, Cary, N.C.

Sharp, J.L. 1985. Submersion of Florida grapefruit in heated water to kill stages of Caribbean fruit fly, Anastrepha suspensa. Proc. F1a. State Hort. Soc. 98:78-80.

Sharp, J.L. 1989. Preliminary investigation using hot air to disinfest grapefruit of Caribbean fruit fly immatures. Proc. Fla. State Hort. Sot. 102157-159.

Sharp, J.L. and V. Chew. 1987. Time/mortality relationships for Anastrepha suspensa (Diptera: Tephritidae) eggs and larvae submerged in hot water. J. Econ. Entomol. 80:646-649.

Sharp, J. L., J.J. Gaffney, J.I. Moss, and W.P. Gould. 1991. Hot-air treatment device for quarantine research. J. Econ. Entomol. 84:520527.

Smoot, J.J. and C.F. Melvin. 1965. Reduction of citrus decay by hotwater treatment. Plant Dis. Rptr. 49:463-476.

Spalding D.H. and W.F. Reeder. 1985. Effect of hot water and gamma radiation on postharvest decay of grapefruit. Proc. Fla. State Hort. Soc. 98:207-208.

U.S. Department of Agriculture. 1985. Plant protection and quarantine treatment manual. Sec. VI: T107. Animal and Plant Health Protection Services, Washington, D.C. 